UDC 1:316.3+340.12

DOI: https://doi.org/10.21564/2075-7190.42.170288

Manuilov Eugene Mykolayovych, $\mathrm{PhD}$ in Philosophy, Professor, professor at Philosophy Department of Yaroslav Mudryi National Law University, Kharkiv, Ukraine e-mail: manuilov1946@gmail.com ORCID ID: 0000-0002-3896-6017

Kalynovsky Yuri Yuriyovych, DSc in Philosophy, Professor, professor at Philosophy Department of Yaroslav Mudryi National Law University,

Kharkiv, Ukraine e-mail: kalina_uu@ukr.net

ORCID ID: 0000-0002-0081-8107

\title{
INFORMATION SOVEREIGNTY OF UKRAINE: MODERN MORAL CHALLENGES AND THREATS
}

The paper discusses the essential properties of Ukrainian information sovereignty from the legal perspective. It demonstrates the correlation between the concepts of "information sovereignty" and "moral sovereignty". The research identifies essential threats to Ukrainian society moral life and their implications for the information sovereignty of Ukraine. Moral security challenges to the Ukrainian community in social media were analyzed. It is emphasized that the state needs to develop further the national strategy of information sovereignty protection.

Keywords: state information sovereignty, state moral sovereignty, moral security, moral security threats, values, public opinion manipulation.

Problem setting. Ukrainian information sovereignty protection is a priority objective for today"s domestic state building. Information threats focused against our country are to be thoroughly analyzed and strategies of their minimization are to be improved. Undoubtedly, information security is a fundamental factor of the existence and development of the modern state. Information wars result in the deformation of the social collective and individual moral values, which affects other areas of the country life, in particular, political, legal, moral and others. In the contemporary conditions of the widespread information technologies, creation of virtual worlds, and the popularity of various social media, the problem of moral and information security has grown and gained new forms and dimensions. On the one hand, the development of information communication technologies significantly 
expands opportunities of a person and society, whereas on the other hand, it conceals a number of threats.

Recent research and publications analysis. The latest research studies normally consider the problem of the state information sovereignty from different perspectives - as an element of ensuring the country national security, as a system factor of state building, as an object of information and hybrid wars etc.

A range of papers deals with the content of such concepts as "information sovereignty", "moral sovereignty", "information security", and "moral security". In particular, O. Kononova devotes her paper to the legal definition of the concept of "information sovereignty". The researcher specifies its essential features in various legal regulations of Ukraine. In turn, I. Kritsak and Ya. Synyak analyze the structure of the state moral sovereignty as the unity of three components - nationalpatriotic idea, religion and law.

In their studies, V. Karlova and D. Mekhed discuss the types and specifics of threats to the moral life of the Ukrainian society, which influence, to a certain extent, the state information sovereignty. V. Karlova classifies these threats as internal and external, while D. Mekhed focuses his research attention on the challenges and hazards in social media. G. Shevchenko emphasizes that the threats to the moral security of the Ukrainian society include the conflict nature and social intellectualization, which are not in line with the individual moral development. According to the researcher, the main moral threats are related to the destruction of the national culture, national science, education and upbringing.

Instead, O. Gida, giving the reasons regarding the benefits of democracy and the freedom of speech notices that there is a threat of their use to manipulate public opinion, influence the political and economic life of the country from the information aspect.

Overall, theoretical studies into the issue of protecting state information sovereignty from the perspective of moral threats and challenges are fragmented and need further elaboration in scientific research.

Paper objective. This work is aimed at identifying the main threats to the Ukrainian society moral life in the context of protecting information sovereignty of Ukraine.

Paper main body. The problem of protecting information sovereignty of Ukraine has become urgent due to the hybrid war, unleashed against our country. Clarifying the terminology it should be mentioned that in regulatory practices the concept of "information sovereignty" first appeared in the Law of Ukraine On Information, which declared that the basis of the information sovereignty of Ukraine is in the national information resources. Ukrainian information resources comprise all their information, regardless of its content, forms, time and place of production. Ukraine independently forms its information resources on its territory and freely 
disposes of them, except for the cases, stipulated by law and international agreements. The concept of "state information sovereignty" was introduced in the Law of Ukraine On National Informatization Program. It is understood as the "ability of the state to control and regulate information flows from outside the country to comply with the laws of Ukraine, rights and freedoms of its citizens, and ensure the national security of the state". In this respect, there are questions both to the content of the definition and to its appropriateness in the above document. Firstly, this concept is not used elsewhere in this law, except for the part that includes the definition. Secondly, even in terms of introduction, it does not seem to be enforceable. Thirdly, it remains unclear why this definition was recorded in the Law of Ukraine On National Informatization Program, which influences a rather specific field of the state policy. Fourthly, while the Law of Ukraine On Information defines the "information sovereignty of Ukraine", the Law of Ukraine On National Informatization Program establishes the definition of the "state information sovereignty". Therewith, the comparison of the essential properties of the suggested definitions proves they are fundamentally different [1, p. 220].

In the context of increased threats to the information sovereignty of Ukraine in the moral and value dimension it is also worth embracing the moral security and sovereignty of the state. Therefore, from our viewpoint, in the contemporary scientific discourse it would be more appropriate to use not only the concept of "information sovereignty", but also a broader concept of the "state moral sovereignty". The moral sovereignty of the Ukrainian state is in the organic unity of the national and common human values, their protection, the development and reproduction as a necessary element of the Ukrainian nation existence, its further establishment as a national-and-cultural community and the subject of international relations. The moral sovereignty of Ukraine establishes the eternal right of our people to form a state, mentality and value-based uniqueness as well as the independence of its national development.

According to researchers, for the analysis of the moral sovereignty it is necessary to refer to the specifics of the structural elements of the concept under consideration and the mechanism of its interaction with other kinds of the sovereignty. I. Kritsak and Ya. Synyak provide evidence that "the moral sovereignty" should be based on three pillars, namely, the national-patriotic idea, religion and law. The above components are tightly interrelated and form a unified mechanism as a "triad of the moral sovereignty". However, the abovementioned elements may exist independently, that is beyond the mechanism of the moral sovereignty, but individually they are unable to play a truly decisive role of implementing state aspirations of the Ukrainian nation, taking into consideration the complexity of the moment for our country. These researchers affirm that the key to success is in the clear interaction and functional efficiency of all the above components of the 
moral sovereignty [2, p. 224]. It is obvious that there is a need to further specify and essentially correlate the concepts of "information sovereignty" and "state sovereignty".

Performing the analysis of the information sovereignty of Ukraine in the context of the existing moral challenges for the society of the country, it is to be emphasized that a pre-requisite for Ukraine entering the global information space is the harmonization of its national legal regulations with international laws in the field of information, regulation of international relations and the interaction in the area of information activities, in particular, as regards ensuring information security. It is required to formally outline the range of external and internal information threats. It is also necessary to clarify and specify the legal definition of the concept of the national information sovereignty, establish its limits, state competence as to its protection, introduce and implement the mechanism of counteracting the threats to information sovereignty, ensure information freedoms, and the freedom of speech as a factor of information security [3, p. 130].

In this respect, V. Kostytsky argues that anti-Ukrainian information war has become a massive threat to the information sovereignty of Ukraine. Today the main form of the information war is psychological aggression, which is effected via the controlled information impact on the individual, group or collective consciousness, the will of the nationals of another country, their feelings, misinformation of the decision-makers in politics, economy and other areas, as well as undermining information opponent's infrastructure [4, p. 264].

It may be claimed that the threats to the information sovereignty of Ukraine have been manifested in the powerful adverse impact on the moral life of our society, attempts to misrepresent national memory, diminish the significance of national values, oppose moral values of various social groups etc.

Scholars believe that moral threats are negative trends, related to the deformation of the value bases of the society. It is considered that external threats in the area of the society moral security include: state policies; blocking equal participation in the international distribution of cultural heritage of the humanity, imposition of alien ideology; the deployment of "cultural expansion" by some countries towards others; the development of the "information war" concept; criminal activities of religious sects, organizations and individuals in their moral practices; the practices of economic and political bodies in the moral field, oriented against the national interests of the country. The internal threats to the moral security are: country's underdevelopment compared to well-developed world powers in terms of social informatization; insufficient cooperation among governmental agencies in establishing and implementing the unified national ideology; the low level of education in the country; unenforceable protection laws, the spread and reinforcement of the traditional national ideals and values [5]. 
The challenges and threats to the Ukrainian society moral life, as the ways of undermining the information sovereignty of Ukraine, may be found in the certain content of social media. In these media the presented information may be of antiUkrainian, anti-human nature, while personal data and the hardware and software of active users in social media are not always properly protected.

In particular, experts prove that under the systematic consideration of different kinds of violations of social media confidentiality protection it is possible to single out the following major types of information threats in social media:

- confidentiality threat (leak of confidential information and direct and indirect losses to the user of a social network);

- integrity threat (modification of information within the network and the loss of its adequacy);

- accessibility threat (hindering access to the media information and blocking access to the resource);

- completeness threat (destruction of information within the network as well as direct and indirect loss both to the user of the social network and to its owner);

- update threat (delay in receiving information by a network legal user);

- importance threat (unauthorized viewing confidential information, which entails the loss of its valuable features);

- focus threat (readdressing media information, which may entail its lower confidentiality and accessibility);

- information overloading threat (multiple copying media information) [6, p. 17].

The moral world outlook of today's youths is especially vulnerable to the destructive impact of social media. Their worldview and value bases are being formed. It is common knowledge that modern social media form the so-called "mosaic thinking", which features non-consistency, fragmentariness and low level of analysis, which becomes the basis for the deformation or unacceptance of moral values. The very essence of this communication does not provide for insights, it is focused on simplifying the message content, speed of its creation and transmission. Human moral qualities become secondary in this interaction, while the key point is the message content and reaction thereto of the widest audience. Under these circumstances the opportunities to affect moral security of an individual and the society, and, therefore, the information sovereignty of the country are considerably strengthened.

American researcher N. Postman rightfully remarks that modern people do not exchange ideas, they exchange images, which is especially evident today at the time of the social media prosperity, including Facebook, Instagram, and others, where the actual main objective of communication and information exchange is mutual entertainment. This communication leaves little space for exchanging 
important ideas or moral or cultural values, since they do not contain entertainment element, which is the basis of the modern means of mass communication and the main aim of communication for the users of these means [7].

From the moral perspective, communication in social media, despite a number of unconditional benefits, is also related to certain threats for the user's privacy, information security of the society and information sovereignty of the state.

For instance, it is common practice to spread disinformation in social media as a way of psychological impact, which is in the deliberate providing the user with the information, which is deceitful and misleading. Misrepresented, incomplete or false data are spread to achieve propaganda, military, commercial or other illegal objectives. A person, who has been misled, in turn, continues spreading false information among users (via friends, groups and pages in social medial services), since this person believes in the false information [8, p. 205]. If the disinformation embraces a considerable number of citizens, it thus creates threats to the state information sovereignty.

Experts convince that the possibilities of the social media technologies bring new corrections to the understanding of the information security. Personal data of users that are publicly accessible, can be used without authorization for advertising, through the fault of the media there may be a leakage of payment details. Serious troubles may emerge for the user in relation to hacking an account and the use of all information against the user, in particular, for political or economic spying, discrediting and revenging. Another threat is the so-called fishing, the virus, which unnoticeably for the user steals his or her login and password, and then uses them for automated spam mailing on behalf of the user to the full list of his or her contacts [9, p. 137].

At the national level, using social networks, information attacks may be performed against whole peoples to destabilize the situation, create favourable moral-and-psychological climate for further manipulative actions, destructive impact on the existing political and economic systems, which eventually leads to undermining information, political and economic sovereignty of the country.

In this context $\mathrm{O}$. Gida suggests that the freedom of speech is a major element of democracy. However, on the other hand, there is a danger of its use to manipulate human consciousness. A specifically trained manipulator is able to force social media users to perceive certain social information in the way favourable for him, and this manipulator channels users' socially significant actions in the way favourable for the customer. Information network impact is mainly focused on undermining and further destruction of fundamental principles of the nation. It is most often performed implicitly and is directed on compromising followed by the removal from the political arena of the nationally conscious elite, who do not share or support manipulator's ideas. Manipulators also widely use the organization of 
provocations and escalation of contradictions between groups with different political views or ethical origin. If necessary, in the future all these may become the grounds for accusations of the power of violating fundamental human rights thus justifying the need of force activities [10, p. 272-273].

The quality of protection against manipulative influence in the information communication space, as the basis of moral security and the state information sovereignty depends on a number of interrelated factors - information culture and the level of subject intellect, their critical thinking development and the ability to work with information, legislation of the country, which regulates the field of information, the specifics of civil society bodies' functioning etc.

In general, state interests in the information area are in creating the conditions for the harmonious development of the country information infrastructure, enforcement of the constitutional human and citizens' rights and freedoms for reinforcing the constitutional order, sovereignty and territorial integrity of the country, establishment of political and social stability, economic prosperity, unconditional enforcement of laws and support of the rule of law, the development of international partnership-based cooperation. The most dangerous sources of threats to the national interests in the field of information are uncontrolled spread of "information weapons", the deployment of arms race in this area, and the attempts to implement the concepts of "information wars" [11, p. 105].

Developing the above ideas, I. Sopilko notes that to prevent information misuse and to protect information rights, the current situation with the national and information security of Ukraine require the development of the evidence-based state policy and strategy in this field, the identification of the system of national values, major and vital interests of individuals, society and state, the identification of external and internal threats to these interests, the search of the effective measures to ensure the security in all areas, the protection from information threats and the exercise of the right to receive reliable information [12, p. 79].

Following G. Shevchenko's opinion, it is necessary to mention that the threats to the moral security include the conflict nature and social intellectualization, which are not in line with the individual moral development, destruction of the national culture, national science, education and upbringing. We emphasize that it is possible to preserve moral security of the society and individual by sticking to national and cultural traditions, by extending them with the spirit of commitment, responsibility, faith in justice, human dignity and honesty as well as morality and beauty. The basis for the moral security may be the moral culture and values, which build the architecture of the personal morality. Kit may be affirmed that the most important moral values of the society include culture, science, education and upbringing that take a person to a higher level of his or her life, encourage formation of the valuebased world outlook, moral world, the system of moral ideals, which enable a person 
to stay a moral human in any life situations and firmly keep their core moral values [13, p. 367-368].

Conclusions of the research. It is possible to argue that the threats and challenges to the moral life of Ukrainian society affect the information sovereignty of Ukraine. Attempting to undermine information independence of the state, destructive forces, both external and internal, are trying to ruin moral foundations of the Ukrainian nation's life, manipulate public opinion, and form anti-state ideas in among the citizens.

\section{СПИСОК ВИКОРИСТАНОЇ ЛІТЕРАТУРИ}

1. Кононова О.В.Господарсько-правове забезпечення інформаційного суверенітету у сфері телерадіомовлення. Економічна теорія та право. 2015. №1. С. 215-225.

2. Кріцак I. В., Синяк Я. В. Духовний суверенітет як цінність та консолідуюча основа української нації. Публічне право. 2016. №. 3. С. 220-230.

3. Бондар Ю. В. Свобода слова як чинник інформаційної безпеки. Актуальні проблеми міжнародних відносин. 2011. Вип. 102 (1). С. 127-130.

4. Костицький В. В. Політико-правові проблеми протидії антиукраїнській інформаційній війні у контексті європейської безпеки. Науковий часопис НПУ імені М. П. Драгоманова. Серія 18: Економіка і право. 2015. Вип. 27. С. 260-269.

5. Карлова В. В. Духовна безпека українського суспільства: виклики, загрози та шляхи їх подолання. 2017. URL: http://matrix-info.com/2017/08/22/duhovnabezpekaukrayinskogo-suspilstva/ (дата звернення: 14.04.2019).

6. Мехед Д. Інформаційна безпека в соціальних мережах. Методи поширення інформації в соціальних мережах. Правове, нормативне та метрологічне забезпепечення системи захисту інформації в Украӥні: наук.-техн. зб. 2015. Вип. 2. C. $14-18$.

7. Postman N. Amusing Ourselves to Death. New York: Penguin Books, 2005. 208 p.

8. Скрута Г. В., Шкарупа I. В., Нікуліщев Г. І. Забезпечення інформаційної безпеки у соціальних мережах. Актуальні задачі та досягнення у галузі кібербезпеки: матеріали Всеукр. наук.-практ. конф., м. Кропивницький, 23-25 листоп. 2016 р. Кропивницький: КНТУ, 2016. С. 204-205.

9. Горова С. В. Проблеми інформаційної безпеки в соціальних мережах. Боротьба з організованою злочинністю і корупиією (теорія і практика). 2014. № 1. С. 136139.

10. Гіда О. Ф. Соціальні мережі як засіб деструктивних впливів через інформаційний простір. Боротьба з організованою злочинністю і корупцією (теорія і практика). 2013. № 3 (спец. вип.). С. 268-278.

11. Дзьобань О. П. Інформаційна безпека в умовах глобалізаційних тенденцій: до проблеми осмислення сутності. Гуманітарний вісник Запорізької державної інженерної академії. 2006. Вип. 24. С. 101-108.

12. Сопілко I. М. Інформаційні загрози та безпека сучасного українського суспільства. Юридичний вісник. Повітряне і космічне право. 2015. № 1. С. 75-80. 
13. Шевченко Г. П. Духовна безпека: духовна культура і духовні цінності сучасної людини. Духовність особистості: методологія, теорія і практика. 2017. Вип. 3. C. 361-373.

\section{REFERENCES}

1. Kononova, O. V. (2014). Gospodars'ko-pravove zabezpechennya informacijnogo suverenittu u sferi teleradiomovlennya. Ekonomichna teoriya ta pravo - Economic Theory and Law, 1, 215-225 [in Ukrainian].

2. Kriczak, I. V., Sy'nyak, YA. V. (2016). Duxovny'j suverenitet yak cinnist' ta konsoliduyucha osnova ukrayins'koyi naciyi. Publichne pravo - Public Law, 3, 220-230 [in Ukrainian].

3. Bondar, YU. V. (2011). Svoboda slova yak chy'nny'k informacijnoyi bezpeky'. Aktual'ni problemy' mizhnarodny'x vidnosy'n - Actual Problems of International Relations, issue 102(1), 127-130 [in Ukrainian].

4. Kosty'cz'ky'j, V. V. (2015). Polity'ko-pravovi problemy' proty'diyi anty'ukrayins'kij informacijnij vijni u konteksti yevropejs'koyi bezpeky'. Naukovy'j chasopy's npu imeni m. p. dragomanova. seriya 18: ekonomika i pravo - Scientific Journal of National Pedagogical Dragomanov University. Series 18: Economics and Law, issue 27, 260-269 [in Ukrainian].

5. Karlova, V. V. (2017). Duxovna bezpeka ukrayins'kogo suspil'stva: vy'kly'ky', zagrozy' ta shlyaxy' yix podolannya. URL: http://matrix-info.com/2017/08/22/ duhovnabezpeka-ukrayinskogo-suspilstva/ [in Ukrainian].

6. Mexed, D. (2015). Informacijna bezpeka v social'ny'x merezhax. metody' poshy'rennya informaciyi v social'ny'x merezhax. Prav., normat. ta metrol. zabezp. sy'stemy'zaxy'stu informaciyi v ukrayini: nauk.-texn. zb. - Legal, regulatory and metrological support of information security system in Ukraine: scientific and technical journal, issue 2, 14-18 [in Ukrainian].

7. Postman, N. (2005). Amusing Ourselves to Death. New York: Penguin Books [in English].

8. Skruta, G. V., Shkarupa, I. V., Nikulishhev, G. I. (2016). Zabezpechennya informacijnoyi bezpeky' u social'ny'x merezhax. Aktual'ni zadachi ta dosyagnennya u galuzi kiberbezpeky': proceedings of the Scientific and Practical Conference. Kropivnitsky: KNTU, 204-205 [in Ukrainian].

9. Gorova, S. V. (2014). Problemy' informacijnoyi bezpeky' v social'ny'x merezhax. Borot'ba z organizovanoyu zlochy'nnistyu i korupciyeyu (teoriya i prakty'ka) - The Fight Against Organized Crime and Corruption (theory and practice), 1, 136-139 [in Ukrainian].

10. Gida, O. F. (2013). Social'ni merezhi yak zasib destrukty'vny'x vply'viv cherez informacijny'j prostir. Borot'ba z organizovanoyu zlochy'nnistyu i korupciyeyu (teoriya i prakty'ka) - The Fight Against Organized Crime and Corruption (theory and practice), 3(specz. vy'p.), 268-278 [in Ukrainian]. 
11. Dz'oban', O. P. (2006). Informacijna bezpeka v umovax globalizacijny'x tendencij: do problemy' osmy'slennya sutnosti. Gumanitarny'j visny'k Zaporiz'koyi derzhavnoyi inzhenernoyi akademiyi - Humanities Bulletin of Zaporizhzhe State Engineering Academy, issue 24, 101-108 [in Ukrainian].

12. Sopilko, I. M. (2015). Informacijni zagrozy' ta bezpeka suchasnogo ukrayins'kogo suspil'stva. Yury'dy'chny'j visny'k. povitryane i kosmichne pravo - Law Journal. Air and Space Law, 1, 75-80 [in Ukrainian].

13. Shevchenko, G. P. (2017). Duxovna bezpeka: duxovna kul'tura i duxovni cinnosti suchasnoyi lyudy'ny'. Duxovnist' osoby'stosti: metodologiya, teoriya i prakty'ka Spirituality of a Personality: Methodology, Theory and Practice, issue 3, 361-373 [in Ukrainian].

Мануйлов Свген Миколайович, кандидат філософських наук, професор кафедри філософії Національного юридичного університету імені Ярослава Мудрого, м. Харків, Україна

Калиновський Юрій Юрійович, доктор філософських наук, професор кафедри філософії Національного юридичного університету імені Ярослава Мудрого, м. Харків, Україна

\section{ІНФОРМАЦІЙНИЙ СУВЕРЕНІТЕТ УКРАЇНИ: СУЧАСНІ ВИКЛИКИ ТА ЗАГРОЗИ ДУХОВНІЙ СФЕРІ}

Постановка проблеми. Захист інформачійного суверенітету є складовою розбудови сучасної України. Наслідком інформачійних війн є деформація духовних иінностей суспільства та особистості, що негативно впливає на інші сфери життедіяльності держсави, зокрема політичну, правову, моральну тощо. 3 одного боку, розвиток інформаційно-комунікаиійних технологій значно розширює можливості людини та суспільства, а з другого - несе в собі низку загроз.

Аналіз останніх досліджень та публікацій. Проблема інформаиійного суверенітету держави в сучасних наукових дослідженнях розглядається у різних ракурсахяк складова забезпечення національної безпеки країни, як системоутворюючий чинник державотворення, як об'єкт інформачійних та гібридних війн. Зокрема, правовому визначенню поняття «інформаційний суверенітет» присвячена робота О. Кононової. У свою чергу, дослідники I. Кріщак та Я. Синяк аналізують структуру духовного суверенітету держави. У наукових розвідках В. Карлової та Д. Мехеда розкрито різновиди й особливості загроз духовній сфері украйнського суспільства, які негативно впливають на інформаційний суверенітет держави. Науковець Г. Шевченко акиентує увагу на тому, що серед загроз духовній безпеиі украйнського соиіуму є конфліктність та інтелектуалізація суспільства, яка не збігається з моральним удосконаленням особистості. 
Мета нашого дослідження полягає у виявленні основних загроз духовній сфері украӥнського суспільства в контексті захисту інформаиійного суверенітету Украӥни.

Виклад основного матеріалу. Стверджується, що в контексті посилення небезпек щүодо інформаційного суверенітету України в духовно-ціннісному вимірі варто вести мову про духовну безпеку та духовний суверенітет натої держави.

Зазначається, щңо посягання на інформаційний суверенітет Украйни знайшли свій прояв у потужних негативних впливах на духовну сферу вітчизняного соиіуму, спробах викривити начіональну пам'ять, зменшити значущістть наџіональних иінностей, протиставити духовні иінності різних соџіальних груп тощзо.

Обгрунтовується, що якість захисту від маніпулятивних впливів у інформаиійно-комунікаиійному просторі як основа духовної безпеки та інформачійного суверенітету держави залежить від низки взаємопов'язаних чинників - інформачійної культури й рівня інтелекту суб'єктів, розвиненості в них критичного мислення та здатності прачювати з інформачією, законодавчої бази краӥни, яка регулює інформаційну сферу, особливостей функціонування структур громадянського суспільства тощо.

Висновки. Загрози та виклики духовній сфері вітчизняного суспільства негативно впливають на інформаційний суверенітет Украӥни. Намагаючись підірвати інформаційну незалежність держави деструктивні сили як ззовні, так $i$ зсередини роблять спроби зруйнувати духовні підвалини життєдіяльності украӥнської нації, маніпулювати суспільною свідомістю, формувати у громадян антидержавницькі настрої.

Ключові слова: інформаційний суверенітет держави, духовний суверенітет держави, духовна безпека, загрози духовній безпеці, иџнності, маніпуляиія суспільною думкою.

Мануйлов Евгений Николаевич, кандидат философских наук, профессор кафедры философии Национального юридического университета имени Ярослава Мудрого, г. Харьков, Украина

Калиновский Юрий Юрьевич, доктор философских наук, профессор кафедры философии Национального юридического университета имени Ярослава Мудрого, г. Харьков, Украина

\section{ИНФОРМАЦИОННЫЙ СУВЕРЕНИТЕТ УКРАИНЫ: СОВРЕМЕННЫЕ ВЫЗОВЫ И УГРОЗЫ ДУХОВНОЙ СФЕРЕ}

Раскрыты сущьностные признаки информационного суверенитета Украины с правовой точки зрения. Показана коррелятивность понятий «информачионный суверенитет» $и$ «духовный суверенитет». Определены основные угрозы духовной 
сфере украинского общества и их опасность для информачионного суверенитета Украины. Проанализирован характер вызовов духовно-информационной безопасности отечественного сочиума в сочиальных сетях. Подчеркивается необходимость дальнейтего развития государственной стратегии Украины относительно зашить информационного суверенитета.

Ключевые слова: информационный суверенитет государства, духовный суверенитет государства, духовная безопасность, угрозы духовной безопасности, иенности, манипуляция общественным мнением.

\section{$\operatorname{soc}$}

